\title{
THE USE OF PREDICT-EXPLAIN-OBSERVE-EXPLAIN IN IMPROVING THE STUDENTS' SPEAKING ABILITY
}

\author{
Andi Asri Jumiaty \\ Prodi Pendidikan Bahasa Inggris, FKIP, Universitas Muhammadiyah Makassar \\ Andiasrijumiaty@unismuh.ac.id
}

\begin{abstract}
This research aimed to explain the improved of the students' accuracy and fluency in speaking. This research employed an Experimental design which was conducted in Pre-Test, Treatment, and Post-Test of five meetings. The location of this research was taken at eleventh year students of SMAN 1 Lilirilau Kabupaten Soppeng with a number of the subject were 35 students. The research findings indicate that the application of Predict-Explain-Observe-Explain was significant in improving the students' accuracy and fluency in speaking. It was proved by the mean score of Pretest was 3.48 then improved to be 8.32 in Post-test. And also there was significant because the result of t-test was 26.88 and t-table was 2.042. It mean that there was the improved of the students' accuracy and fluency in speaking.
\end{abstract}

Keywords: Predict-Explain-Observe-Explain, Experimental design, speaking accuracy, speaking fluency.

\section{INTRODUCTION}

Speaking is one of activities in communication. It is one form of information through oral communication in the world and it becomes more and more useful. Communication is essentially a process of sending and receiving message. Communication among people is complicated because it is required the sender of message to express what he or she intends to communicate and for the reciver to interpret the message accurately. In this case, language plays an important rule which must be produce to convey our ideas, feeling in our life.

Many students considered learning English especially speaking difficult subject. This difficulty is caused by phsychology factor of the students and lack of teachers' creativity in teaching speaking. Roch (2007) stated that this problem related extremely with the use of teaching strategy.

The teacher always gives the materials of learning speaking for only instructing and giving example to the students, they just concentrate in learning visually without caring the students' motivation and competence. So, the teaching and learning process make the students bored and have low motivation to follow 
the teaching learning process. This condition influences failure in education specially teaching foreign language. Djamarah and Zain (2002) said to teach someone, a teacher has to choose a suitable learning model because this can influence the students' learning outcome.

Realizing that speaking is not easy to learn, both teacher and students should be preparing themselves to learn it. Teacher as subject of learning process are demanded to be more creative in presenting the lesson (speaking) by making some strategies or method that can be used in teaching process. While students as object of learning process are demanded to more active in learning speaking. No one is doubt; the interaction is the key to improve speaking ability.

\section{CONCEPT OF SPEAKING}

\section{Definition of Speaking}

Oral comunication is a two-way process speaker and listener, and involves the productive skill of speaking and the receptive skill of listening (undertanding). It is important to understand that receptive does not imply passive both in listening and reading language users are actively involved in the process of interpreting ang negotiating meanings.

Revel (2007) states that communicative is an exchange between people, of knowledge, of information, of ideas, of opinion, of feeling so the must to be a concept ideas and follow, of what they are going to say.

Widdowson (1985) states that an act of communication through speaking is commonly perform in fase interaction and accord as a part of dialogue or rather of verbal exchange.

Brown (1999) concludes that speaking is an interactive process of constructing meaning that involves producing and receiving and processing information.

Chainstand (2006) concludes that speaking is learning to speak is abiously more difficult than learning to understanding the spoken language.

While Chaney (2006) states that speaking is the process of building and sharing meaning through the use of verbal and non-verbal symbols, in a variety of contexts. 
From the above definition, it can be inferred that speaking is an exchange of knowledge and interactive process of building and sharing ideas, opinion, and feeling that involves producing and recieving information. Additionally, the teachers who concentrate on accuracy help their students to produce grammatically correct written and spoken English (Sangkala, 2012)

\section{The Elements of Speaking}

According to Harmer, (1991:159) aspects of speaking can be divided as follow:

Accuracy

Based on the Webster dictionary (1959) accuracy is the quality of being accurate while in oxford dictionary in Khaerat (1991) accuracy is degree of being correct so the accuracy in speaking ability is the quality if being accurate in speaking. English ability in this case divided into things. They are pronunciation, vocabulary, and grammar (structure).

\section{Pronunciation}

Pronunciation is an act or result producing the sound of speech including articulation, vowel formation, accent and inflection. Sometimes the listener does not understand what we talking about because lack in pronunciation. Pronunciation is the fact of manner of articulate utterance. Certainly, pronunciation can not be separated from intonation and stress use, which are the indicators of someone whether he has good pronunciation in language spoken. Furthermore pronunciation and stress are largely learned successfully by imitating and repetition.

\section{Vocabulary}

Vocabulary is very important in speaking English. It is impossible to speak without mastery of vocabulary. Therefore, this element is somewhat essential to learn before practicing speaking. The students sometimes get trouble in memorizing all vocabulary that they have known because they seldom practice and use them. Thus, it needs to keep them in their mind.

Based on the Webster dictionary (1959), vocabulary is all words used by person or group and several definition of the words have given different writers 
such as Charles F. Hokket in Samad (1889:26). A word is thus any segment of a sentences bounded by successive points at which pausing is possible.

Harmer (1991:135) divides vocabulary in two types that is active vocabulary and passive vocabulary. Active vocabulary is the words that students have learned and they expect to be able to use them. Passive vocabulary is the words they can recognize but cannot be produced. Someone can be considered of having good vocabulary use, when the vocabulary produced is wide appropriate with certain situation of dialog of speech.

\section{Grammar}

One factor of in influencing the students' speaking skill is the functional grammar, the fact shows that the students sometimes want to speak with other people but they have lack of functional grammar.

Based on the Webster dictionary (1959) grammar is being of rules for the use of the words. In speaking skill, grammar always to be handicaps in performs pure speaking. It causes by the speaker some times afraid to make mistake of grammar in perform speaking while the arrangement of words in a sentence is not the same in difficult language, they are not even the same in sentences patterns.

Thus, if a students does not recognize the signal of the sentence for instant that "is he a lecturer?", signal a question, that "M. Basri can teach", signal a statement, and that “ didn't she swim?", signal a negative question. He is probably missing significance of word order arrangement.

As for the use of grammar signal, students should learn it by acquiring a set of habits and not merely by recording examples of usage. It has been stated that sentences patterns, students should be trained to acquire the habit of producing it automatically. This is best one through oral pattern practice. For instance, students imitate the teacher in producing a certain pattern as "he is a lecture in such a way that they can produce it with relatives' case. Such a practice involves intonation, stress as well as phonemes in this case the teacher must be a good model.

Fluency

Based on Webster Dictionary (1991) fluency is ready and expressive use of language, it is probably best achieved by allowing the "stream" of speech to "flow" 
then, assume of this speech spills over beyond comprehensibility the river bank' of instruction or some details of phonology, grammar or discourse explained that fluency defined as the ability to get across communicative intent without to much hesitation and too many pauses or breakdown in communication: it refers to how well you communicate in natural manner. It is possible to be fluent build not accurate, and vise versa, that is accurate but not fluent.

Byrne (1987:78) states that the main goal in teaching the produce speaking skill will be oral fluency. This can be differed as the ability to express oneself intelligibly reasonable accurately and without too much hesitation (otherwise communication my break down because the listener loses in interest o best impatient. To attaint this goal, you will have to bring the students from the stage where they are mainly imitating a model of some kind or responding to cues, to the point where they can use language fluency to express their own ideas.

Based on the statement above, the researcher can conclude that fluency refers to be able to speak smoothly, and easy flow word or to person able to communication with base it suggested the ready flow an accomplished speaker and writer, it is usually a term of commendation.

\section{Types of Classroom Speaking Performance}

Heaton (1989:115) divides that oral communication consists of four general types:

1. Intra personal communication, in which individual communicates with himself or herself usually by thinking but occasionally aloud

2. Interpersonal communication, in which two individuates communicate with each other face to face.

3. Group communication, in which several students meet face to face discuss whatever matter, may beat hard and in which those students share the source and receive ideas.

4. Public communication, in which one speaker present a message to a group of receivers in a face-to-face setting. While the receiving occasionally may adopt the source role, generally the speaker does most orally or the talking. 
In speaking class, the students are expected to express the ideas, information and feelings to the other. Practicing use the language is very important in order to develop the students' ability in speaking. The students will not be able to speak fluently if they do not practice the language in good, correct and accurate manner.

\section{Characteristics of a Successful Speaking Activity}

Speaking skill which is also known as oral skill, it is very important in human interaction when people communicate with each other. There are two basics that can carry out human activities in communication with language, namely speaking and listening. In speaking the people put their ideas into word for other people or group novel that they can understand what they say and hope people or group can give them feedback. So, in oral communication, there are two ways process between speaker and listener, they are the productive skill of speaking and the receptive skill of understanding.

Ur (1995:115) in Fitriani (2011:20) states that, the students who know a language a referred to as "speaker" of language, as if speaking includes all other kinds of knowing and may if not most foreign language students are prima in learning to speech. He gave some characteristics when the speaking activity can be said have been successful. They are as follows:

1. The students talk a lot. The students should get as much as possible chance to speak. But, unfortunately, it is most usually time is taken up with the teachers talk or pause.

2. Participation is event. All students should get some chance to speak and give contributions; classroom discussion is not dominated by a minority of talkative participants.

3. Motivation is high. The students are full of desire to speak; because they are interested in the topic and have something new to say about it.

4. Language is of an acceptable level. The students express themselves in utterances that are relevant, easily comprehensible to each other and of acceptable level of language accuracy.

When the students study language they also think of now people speak and understanding each other. Speaking skill which is also known as oral skill plays a 
very important role in human interaction when people communicate their ideas to the other. Speaking is required to communicate idea, opinion and comments to make contact with other people in conversational situation. Almost of us learn speak and fact speaking is so much a part of daily life. However to speak involves developing a number of complex skills and different types of knowledge about how and when to communicate.

Speaking in the classroom has two functions: one is to learn the language; the other is to use it as people do in real life. The two functions often overlap: speaking to learn can lead to speaking to communicate, and this in turn consolidates learning. But the precondition for communication is learning, so that pupils are in a position to accomplish the last three steps of the planning and execution process.

\section{What is Predict-Explain-Observe-Explain Method?}

The writer in this case, will like to give the definition about Predict-ExplainObseve-Explain Method. This method uses in improving the speaking ability. Predict-Explain-Obseve-Explain Method come from the discrepant events because there are many events that surprise us. We expact that one thing will happen, and something else happen listened. As a result of this observations, the PredictExplain-Obseve-Explain Method was developed.

According to Purnomo (2010), learning Predict-Explain-Observe-Explain model using four main steps, namely:

a. Prediction is a process of making allegations against an event. In making the allegation students already think of a reason why they make such allegations. In this process students are given the widest possible freedom arrange alleged by reason, teachers should not limit students' thinking so that many ideas and concepts that emerged from the mind of students. In the prediction process, the teacher can also understand that a lot of misconceptions about what happens to students. It is important for teachers to help students to establish a correct concept.

b. Explanation is a process where students have to explain why they make allegations like that. 
c. Observation is to do the research, observation of what is happening to test the prediction that they convey truth. The most important thing in this step is a confirmation of their predictions.

d. Explanation is the briefing especially about the conformity between allegation and the results of the observation phase. If the result is consistent with the predictions and observations after they obtain an explanation of the truth of his prediction, then the students are more positive concept. However, if the suspicions are not right then the student can find an explanation of the inaccuracy of predictions. Students will experience a change in the concept of a concept that is not true become true. Here, students can learn from their mistakes, and generally learn from mistakes will not be easily forgotten.

The things that need to be considered in the Predict-Explain-ObserveExplain learning model is as follows:

1) The issue should be raised to trigger a problem of cognitive conflict and spark curiosity.

2) Predictions must be accompanied by a rational reason. Prediction is not just guessing.

3) The demonstration must be observed clearly, and can provide answers to the problem.

4) Students involved in the explanation.

White and Gustone (1992) introduced the Predict-Explain-Observe-Explain as a model of efficient learning to generate ideas or ideas of students and a discussion of their ideas. Procedures of Predict-Explain-Observe-Explain Method are students' prediction of the results of the demonstrations, explained their prediction, discussed the reason of their prediction, and finally explained the results of prediction of their observations.

How the strategy works:

a. Asking students to predict first what will happen.

b. Asking students to explain the reasons for their predictions gives the teacher indications of their theories. This can be useful for uncovering 
misconceptions or developing understandings they have. It can provide information for making decisions about the subsequent learning.

c. Evaluating their predictions and listening to others' predictions helps students to begin evaluating their own learning and constructing new meanings.

d. Explaining their predictions about the conformity between allegation and the results of the observation.

According to Liew \& Treagust (1995), Predict-Explain-Obseve-Explain is a teaching strategy that probe understanding by requiring students to carry out four tasks. Firstly, the students must predict the outcome of some event and must justify their prediction. Secondly, they explain why they believe thier prediction. Thirdly, they describe what they see happen and finally they must reconcile any conflict between prediction and observation.

Richard Gunstone has done a lot of research on discrepant events and on the use of this teaching strategy to bring out conceptual change in children. He said that one intresting thing I have noticed for students with discrepant events is that, unless we have the students hypothesize what will happen, they don't even notice the event is discrepant. The next time we ask them to predict what will happen, they predict what they expect to happen rather than what they saw happen in the actual situation.

But, there are hints for this method namely, at least half of the PredictExplain-Observe-Explain Method we use in the classroom sould be non-discrepant events. Because, we want our students to make reasonable predictions. It is better to choose events which are normally discrepant.

Practicalities:

Step 1: Predict:

Describe to the students what we are going to do. Then ask them to predict what will happen.

Step 2: Explain:

Ask them why they believe that. An important part of science is to make our ideas explicit. The most common form of communication we use is language and the easiest form of language to use in the classroom are talk. So, ask the students to tell about why they believe what they believe. 
Step 3: Observe:

Ask the students to observe what they believe.

Step 4: Explain:

Ask the students to hypothesize about why things happened the way they did.

\section{METHOD}

In this research, the researcher used pre-experimental design. It was aimed to find out the effectiveness of Predict-Observe-Explain method in improving the students' speaking ability at eleventh year of SMAN 1 Lilirilau Kabupaten Soppeng.

The design could be represented as follow:

\begin{tabular}{|c|c|c|}
\hline Pre-test & Treatment & Post-test \\
\hline O1 & $\mathrm{X}$ & $\mathrm{O} 2$ \\
\hline
\end{tabular}

\section{Pre-test}

Before doing the treatment the students were given pre-test to know their prior's achievement in speaking. The researcher asked the students to explain/ describe one topic like "what do you think about global warming?".

\section{Treatment}

After giving the pre-test, the students were treated by using Predict-ExplainObseve-Explain method. The treatment's steps as follow:

a. The research described the teaching material.

b. The researcher asked the students to predict first what will happen.

c. The researcher asked the students to explain the reasons for their predictions.

d. The researcher asked the students to observe their predictions.

e. The researcher asked the students to explain their predictions about the conformity between allegation and the results of the observation. 


\section{Post-test}

After the treatment, the post-test was conducted to find out the students' speaking ability. It was used to check the result of treatment, it was also useful to know whether the Predict-Explain-Obseve-Explain method is effective to improve the students' speaking ability.

\section{Research Variables and Indicators}

The researcher includes two variables in this research; namely dependent and independent variables.

1. The independent variable is the use of Predict-Explain-Observe-Explain.

2. The dependent variable is the students' speaking skill.

Related to variables above, the researcher also includes indicators in this research are :

a. The students' speaking accuracy in English includes pronunciation, vocabulary and grammar.

b. The students' speaking fluency.

\section{Instrument of the Research}

The research used speaking test to asses and examine the students' speaking ability. The tests were pre-test and post-test. The pre-test was given to asses and examine the students' prior speaking ability treatment while post-test was given after treatment of using Predict-Explain-Observe-Explain method as the manner to asses and examine the students' speaking ability. Both of pre-test and post-test were used to find out the improvement of the students' speaking ability after treatment by using Predict-Explain-Obseve-Explain method.

\section{FINDINGS AND DISCUSSIONS}

\section{A. Findings}

The data were collected by administrating the test, the tests were done twice namely pre test and post-test, the pre-test was given before the treatment and the post-test was given after treatment.

\section{The Improvement of the Students' Accuracy}

The the use of Predict-Explain-Observe-Explain in improving the students' speaking ability deals with accuracy and fluency. The improvement of the students' 
accuracy dealing with pronunciation, vocabulary and grammar at the eleventh year students of SMAN 1 Lilirilau Kabupaten Soppeng can be seen clearly in the following table:

Table 1. The Improvement the Students' Accuracy

\begin{tabular}{|l|l|c|c|c|}
\hline \multirow{2}{*}{ No. } & \multirow{2}{*}{ Indicators } & \multicolumn{2}{|c|}{ Mean score } & The Improvement \\
\cline { 3 - 5 } & & Pre-test & Post-test & \\
\hline 1. & Pronunciation & 2.08 & 3.94 & 1.86 \\
\hline 2. & Vocabulary & 1.77 & 4.17 & 2.4 \\
\hline 3. & Grammar & 1.62 & 4.14 & 2.52 \\
\hline 4. & $\sum X$ & 5.47 & 12.25 & 6.78 \\
\hline 5. & $\bar{X}$ & 1.82 & 4.08 & 2.26 \\
\hline
\end{tabular}

The table 1 above indicates the significant improvement of the students' accuracy. The mean score of pronunciation in pre-test is categorized as poor (2.08). The mean score of pronunciation in post-test is categorized as good (3.94). The mean score of vocabulary in pre-test is categorized as poor (1.77). The mean score of vocabulary in post-test is categorized as good (4.17). The mean score of grammar in pre-test is categorized as poor (1.62). The mean score of grammar in post-test is categorized as good (4.14).

Therefore, the use of Predict-Explain-Observe-Explain method in teaching and learning process can improving the students' accuracy in pre-test and post-test. The students' achievement in post-test is greater than in pre-test $(4.08>1.82)$.

\section{The Improvement of the students' Fluency}

The the use of Predict-Explain-Observe-Explain in improving the students' speaking ability deals with accuracy and fluency. The improvement of the students' fluency at the eleventh year students of SMAN 1 Lilirilau Kabupaten Soppeng can be seen clearly in the following table: 
Table 2. The Improvement the Students' Fluency

\begin{tabular}{|l|c|c|c|}
\hline \multirow{2}{*}{ Indicator } & \multicolumn{2}{|c|}{ Mean score } & The Improvement \\
\cline { 2 - 4 } & Pre-test & Post-test & \\
\hline Fluency & 1.65 & 4.25 & 2.6 \\
\hline
\end{tabular}

The table 2 above indicates the significant improvement of the students' fluency. The mean score of fluency in pre-test is categorized as poor (1.65). The mean score of fluency in post-test is categorized as good (4.25).

Therefore, the use of Predict-Explain-Observe-Explain method in teaching and learning process can improving the students' fluency in pre-test and post-test. The students' achievement in post-test is greater than in pre-test $(4.25>1.65)$.

\section{The Improvement of the Students' Speaking Ability}

The the use of Predict-Explain-Observe-Explain in improving the students' speaking ability deals with accuracy and fluency. The improving of the students' speaking ability dealing with accuracy and fluency can be seen clearly in the following table:

Table 3. The improvement the students' Speaking Ability

\begin{tabular}{|l|c|c|c|c|}
\hline \multirow{2}{*}{ No. } & \multirow{2}{*}{ Variable } & \multicolumn{2}{|c|}{ Mean score } & \multirow{2}{*}{ The Improvement } \\
\cline { 3 - 4 } & & Pre-test & Post-test & \\
\hline 1. & Accuracy & 1.82 & 4.08 & 2.26 \\
\hline 2. & Fluency & 1.65 & 4.25 & 2.6 \\
\hline 3. & $\sum X$ & 3.47 & 8.33 & 4.86 \\
\hline 4. & $\bar{X}$ & 1.73 & 4.17 & 2.43 \\
\hline
\end{tabular}

The table 3 above indicates that the mean score of pre-test, accuracy is greater than fluency $(1.82>1.65 \mathrm{~b})$. The mean score of post-test, fluency is greater than accuracy $(4.25>4.08)$. The table above also indicates the significant improvement of the students' accuracy and fluency. The mean score of accuracy in pre-test is categorized as poor (1.82). The mean score of accuracy in post-test is categorized as good (4.08). The mean score of fluency in pre-test is categorized as poor (1.65). The mean score of fluency in post-test is categorized as good (4.25).

Therefore, the use of Predict-Explain-Observe-Explain method in teaching and learning process can improving the students' speaking ability in pre-test and 
post-test. The students' achievement in post-test is greater than in pre-test (4.17 > $1.73)$.

\section{Mean score and standard deviation of tests in Speaking Ability}

Table 4. The mean score and the standard deviation of tests

\begin{tabular}{|l|c|c|}
\hline \multicolumn{1}{|c|}{ Kind of Test } & Mean Score & Standard Deviation \\
\hline Pre-test & 3.48 & 1.47 \\
Post-test & 8.32 & 1.43 \\
\hline
\end{tabular}

Table 4 above shows that the mean score of pre-test is 3.48 , and that of the post-test is 8.32. It means that the mean score of the post-test greater then that of the pre-test. It means that the students could improve their speaking ability after treatment. The standard deviation of the pretest is 1.47 which greater than he standard deviation of the post-test, 1.43, but almost equal.

\section{Hypothesis Testing}

In order to see whether or no there is a significant difference between the result of the pre-test and post-test of the students, the t-test was to be applied. The test variables (pre-test and post-test) are statistically different on alpha level (@)= 0.05 , at the degree of freedom (df) $\mathrm{N}-1=34$. To see the difference, look at table below.

Table 5. Hypothesis testing

\begin{tabular}{|c|c|c|}
\hline Variable & $\mathrm{t}$-test value & $\mathrm{t}$-table \\
\hline $\mathrm{X}_{2}-\mathrm{X}_{1}$ & 26.88 & 2.045 \\
\hline
\end{tabular}

Table 5 above indicates that the value of the t-test (26.88) is greater than the value of the t-table (2.045). It means that there is a significant difference between the result of the pre-test and post-test of the students.

Seeing the result above it can be concluded that the null hypothesis $\left(\mathrm{H}_{0}\right)$ is rejected whereas the alternative hypothesis $\left(\mathrm{H}_{1}\right)$ is accepted. In other words, the use of predict-explain-observe-explain can improve the students' speaking ability.

\section{DISCUSSIONS}

In this part, discussion dealing with the interpretation of findings derived from the result of findings of the students' speaking ability in terms of accuracy 
dealing with pronunciation, vocabulary and grammar, fluency dealing with selfconfidence. The result of the data analysis through speaking test showed that the students' speaking ability in terms of accuracy and fluency improvement significantly. The mean score of the students in pre-test is 1.73 that is classified as poor and post-test is 4.17 that is classified as good. Those score got from the result of the students' accuracy and fluency.

The students' accuracy at the eleventh year of SMAN 1 Lilirilau Kabupaten Soppeng in 2012/2013 academic year through Predict-Explain-Observe-Explain method. The indicator of pronunciation of the students' accuracy in pre-test have improvement from post-test. The improvement can be seen after testing. The students' pronunciation improved which improvement 1.86 and the students' mean score is 3.94 that is classified as good. The indicator of vocabulary of the students' accuracy in pre-test have improvement from post-test. The improvement can be seen after testing. The students' vocabulary improved which improvement 2.4 and the students' mean score is 4.17 that is classified as good. The indicator of grammar of the students' accuracy in pre-test have improvement from post-test. The improvement can be seen after testing. The students' grammar improved which improvement 2.52 and the students' mean score is 4.14 that is classified as good.

The students' fluency at the eleventh year of SMAN 1 Lilirilau Kabupaten Soppeng in 2012/2013 academic year through Predict-Explain-Observe-Explain method. The students' fluency in pre-test have improvement from post-test. The improvement can be seen after testing. The students' fluency improved which improvement 2.6 and the students' mean score is 4.25 that is classified as good.

\section{CONCLUSION}

Based on the result and the discussion of the data analysis previously, the writer takes conclusion. The speaking ability at the eleventh year students of SMAN 1 Lilirilau Kabupaten Soppeng in Academic year 2012-2013 is still low before using Predict-Explain-Observe-Explain Method. It is proven by the mean score of the pre-test (3.48), than improved after treatment by using Predict-ExplainObserve-Explain Method. The mean score of post-test (8.32) was aduequately proved the statement. It means that the speaking ability at the eleventh year students 
of SMAN 1 Lilirilau Kabupaten Soppeng improved about after applying PredictExplain-Observe-Explain Method. Predict-Explain-Observe-Explain Method has significant role to improve speaking ability at the eleventh year students of SMAN 1 Lilirilau Kabupaten Soppeng. It is proved by the t-test value(26.88) which is higher than the t-table value (2.042)

\section{BIBLIOGRAPHY}

Arikunto, Suharmisi. 1998. Prosedur Penelitian ( suatu pendekatan praktek). Jakarta: PT.Rineka Cipta

Arsyad, azhar. 2006. Media pembelajaran. Jakarta: PT. Raja Grafindo Persada

Brown, H. Douglas. 1994. Teaching by Principle : An Interactive Approach Language Pedagogy. New York: Prentice-Hall, Inc

Brown in Florez (1999) http://sibungsuinred.blogspot.com/2011/10/teachingspeaking.html

Byrne, Donn. 1987. Teaching Oral English Singapore. Longman Singapore Publisher.

Chastain. Kenneth. 1976. Developing Second Language Skills; Theory to practice; Third Edition; McNally College Publishing Company

Depdikbud. 1985. Petunjuk pelaksanaan proses belajar mengajar dan petunjuk pelaksanaan system penilaian. Jakarta: Depdikbud

Doff, Adrin. 1998. Teach English, training course for teachers. Australia: Cambridge University

Gay, L. R, 1981. Educational Research: Competencies for Analysis and Application. Columbus: A Bell and Howell Company, Charles, E. Merril Publishing Co

Heaton, J.B.1989. Writing English Language Test. New York: Longman Group UK Company 
Harmer, J. 1991. The Practice of English Language Teaching London an New York. Longman Group

Liew, Wah. 2004. The Effectiveness Predict-Explain-Observe-Explain Technique in Diagnosing Student's Understanding of Their scienceand Identifying Level of Achievement. Africa: University of Natal

Sangkala, I. (2012, May). The Implementation of "ARIAS" Strategy to Increase Students Speaking Skill at SMA Negeri 1 Bungoro. Exposure, 1(1), 59-76. doi:http://dx.doi.org/10.26618/ejpbi.v1i1

Sudjana, N., Rivai, A. 1999 Media pembelajaran. Bandung: PT. Tarsito

Sudjana, N. 1982. Metode statistika. Bandung : PT.Tarsito

Webster's. 1959. Third New International Dictionary. A.B., Dartmouth College; A.M., Harrad University; Ph.d., Columbia University

Widowson, H.G. 1985 Teaching Language as Communication. New York; Oxford University Press 